Georgetown University Law Center

Scholarship @ GEORGETOWN LAW

1990

\title{
Our Rights and Obligations to Future Generations for the Environment
}

Edith Brown Weiss

Georgetown University Law Center, weiss@law.georgetown.edu

This paper can be downloaded free of charge from:

https://scholarship.law.georgetown.edu/facpub/1627

84 Am. J. Int'I L. 198 (1990)

This open-access article is brought to you by the Georgetown Law Library. Posted with permission of the author.

Follow this and additional works at: https://scholarship.law.georgetown.edu/facpub

Part of the Environmental Law Commons, and the International Law Commons 
blessed with the intelligence to figure out how to survive in an environment where we are not physically the strongest, fastest or best-protected animals. That same intelligence can be stretched to include a world-based empathy for the environment, "beneficent" in Parfit's sense.

We should not limit our actions to those we are able to determine now as directly or indirectly benefiting ourselves or our descendants. Rather, we should cultivate our natural sense of obligation not to act wastefully or wantonly even when we cannot calculate how such acts would make any present or future persons worse off. ${ }^{25}$ There is good evidence that customary international law — with various fits and starts and setbacks - is moving generally in this direction, perhaps responding to a deep and inarticulate sense that human beings are not in confrontation with, but rather belong to, their natural environment. That such law is currently given the label "human rights" should not constrict our understanding of what it is or where it is going.

Anthony D'Amato*

\section{OUR Rights AND Obligations to Future GENERATIONS FOR THE ENVIRONMENT}

This we know: the earth does not belong to man: man belongs to the earth. . . . Whatever befalls the earth, befalls the sons of the earth. Man did not weave the web of life: he is merely a strand in it. Whatever he does to the web, he does to himself.

Chief Seattle $\dagger$

We read every day about the desecration of our environment and the mismanagement of our natural resources. We have always had the capacity to wreck the environment on a small or even regional scale. Centuries of irrigation without adequate drainage in ancient times converted large areas of the fertile Tigris-Euphrates valley into barren desert. What is new is that we now have the power to change our global environment irreversibly, with profoundly damaging effects on the robustness and integrity of the planet and the heritage that we pass to future generations.

In Fairness to Future Generations argues that we, the human species, hold the natural environment of our planet in common with all members of our

\footnotetext{
${ }^{25}$ This would be a pure example of deontological ethics in Kant's sense. For a brief discussion and references, see D'Amato \& Eberle, Three Models of Legal Ethics, 27 ST. Louis U.L.J. $761,772-73$ (1983) ("a deontological theory of ethics says that some acts are morally obligatory regardless of their consequences for human happiness").

* Of the Board of Editors.

$\dagger$ Letter from Chief Seattle, patriarch of the Duwamish and Squamish Indians of Puget Sound, to U.S. President Franklin Pierce (1855). Although the letter appears in numerous anthologies, the original has never been located.
} 
species: past generations, the present generation, and future generations. ${ }^{1}$ As members of the present generation, we hold the earth in trust for future generations. At the same time, we are beneficiaries entitled to use and benefit from it.

There are two relationships that must shape any theory of intergenerational equity in the context of our natural environment: our relationship to other generations of our own species and our relationship to the natural system of which we are a part. ${ }^{2}$

The human species is integrally linked with other parts of the natural system; we both affect and are affected by what happens in the system. The natural system, contrary to popular belief, is in many ways a hostile one. Deserts, glaciers, volcanoes, tsunamis can bring havoc to our species. Moreover, the natural environment can be toxic to our species, as through the natural toxicity of some plants and animals or the dramatic release of toxic clouds of carbon dioxide from Lake Nyos in the Cameroon, which killed 1,700 people. On the other hand, the natural system makes life possible for us. It gives us the resources with which to survive and to improve human welfare.

Our actions affect the natural system. We alone among all living creatures have the capacity to shape significantly our relationship to the environment. We can use it on a sustainable basis or we can degrade environmental quality and the natural resource base. As part of the natural system, we have no right to destroy its integrity; nor is it in our interest to do so. Rather, as the most sentient of living creatures, we have a special responsibility to care for the planet.

The second fundamental relationship is that between different generations of the human species. All generations are inherently linked to other generations, past and future, in using the common patrimony of earth. ${ }^{3}$

To define intergenerational equity, it is useful to view the human community as a partnership among all generations. In describing a state as a partnership, Edmund Burke observed that "as the ends of such a partnership cannot be obtained in many generations, it becomes a partnership not only between those who are living but between those who are living, those who

\footnotetext{
${ }^{1}$ E. Brown Weiss, In Fairness to Future Generations: International Law, Common Patrimony and Intergenerational EQuity (1989).

${ }^{2}$ The field of human ecology studies this relationship. See READINGS IN MAN, THE ENVIRONMENT, AND HumAN ECOLOGY (A. S. Boughey ed. 1973) (good selection of readings in human ecology); R. \& P. WATSOn, Man And NATure (1969) (thoughtful essay).

${ }^{3}$ Professor D'Amato criticizes existing theories of equity for depending on "an articulate link to the improvement of the human condition" (i.e., as anthropocentric), rather than on a moral relationship with nature itself. It is certainly true that In Fairness to Future Generations is concerned with equity among generations of the human species. But it is equity with regard to the care and use of the planet, which is explicitly rooted in the recognition that the human species is part of the natural system. This implies great respect for the natural system of which we are a part, but it does not imply that all other living creatures are or should be treated equally. Rather, the human species, as a part of this natural system, has a special obligation to maintain the integrity of the planet, so that all generations will be able to enjoy its fruits.
} 
are dead, and those who are to be born." 4 The purpose of human society must be to realize and protect the welfare and well-being of every generation. This requires sustaining the life-support systems of the planet, the ecological processes and the environmental conditions necessary for a healthy and decent human environment.

In this partnership, no generation knows beforehand when it will be the living generation, how many members it will have, or even how many generations there will ultimately be. It is useful, then, to take the perspective of a generation that is placed somewhere along the spectrum of time, but does not know in advance where it will be located. ${ }^{5}$ Such a generation would want to inherit the earth in at least as good condition as it has been in for any previous generation and to have as good access to it as previous generations. This requires each generation to pass the planet on in no worse condition than it received it in ${ }^{6}$ and to provide equitable access to its resources and benefits. Each generation is thus both a trustee for the planet with obligations to care for it and a beneficiary with rights to use it.

Intergenerational equity calls for equality among generations in the sense that each generation is entitled to inherit a robust planet that on balance is at least as good as that of previous generations. This means all generations are entitled to at least the planetary health that the first generation had. ${ }^{7}$ In practice, some generations may improve the environment, with the result that later generations will inherit a richer and more diverse natural resource base. In this case, they would be treated better than previous generations. But this extra benefit would be consistent with intergenerational equity, because the minimum level of planetary robustness would be sustained and later generations would not be worse off than previous generations. The converse is also possible, that later generations would receive a badly degraded environment with major loss of species diversity, in which case they would be treated worse than previous generations. This latter case would be contrary to principles of intergenerational equity. Equity among generations provides for a minimum floor for all generations and ensures that each generation has at least that level of planetary resource base as its ancestors. This concept is consistent with the implicit premises of trusteeship, stewardship and tenancy, in which the assets must be conserved, not dissipated, so that they are equally available to those who come after.

The theory of intergenerational equity finds deep roots in international law. ${ }^{8}$ The Preamble to the Universal Declaration of Human Rights begins, "Whereas recognition of the inherent dignity and of the equal and inalienable rights of all members of the human family is the foundation of freedom, justice and peace in the world." The reference to all members of the human

${ }^{4}$ E. BURKe, Reflections on the Revolution in France 139-40 (1790), in 2 WORKS OF EDMUND BURKE 368 (London 1854).

${ }^{5}$ See J. Rawls, A Theory Of Justice (1971).

${ }^{6}$ See Callahan, What Obligations Do We Have to Future Generations?, in ResPonsibilities to Future Generations 73 (E. Partridge ed. 1981).

${ }^{7}$ See B. Ackerman, Social Justice in the Liberal State (1980).

${ }^{8}$ E. BROWN WeIss, supra note 1 , at 25-26. 
family has a temporal dimension, which brings all generations within its scope. The reference to equal and inalienable rights affirms the basic equality of these generations in the human family.

The United Nations Charter, the International Covenant on Civil and Political Rights, the Convention on the Prevention and Punishment of the Crime of Genocide, the American Declaration on the Rights and Duties of Man, the Declaration on the Elimination of Discrimination against Women, the Declaration on the Rights of the Child and many other human rights documents protect the dignity of all people and the equality of their rights. The Declaration of the Principles of International Cultural Co-operation provides in Article 1 that "each culture has a dignity and value which must be respected and preserved," and that "all cultures form part of the common heritage belonging to mankind." These instruments reveal a fundamental belief in the dignity of all members of human society and in an equality of rights that extends in time as well as space. Indeed, if we were to license the present generation to exploit our natural and cultural resources at the expense of the well-being of future generations, we would contradict the purposes of the United Nations Charter and international human rights documents.

It is not enough, however, to apply a theory of intergenerational equity only among generations. It also carries an intragenerational dimension. When future generations become living generations, they have certain rights and obligations to use and care for the planet that they can enforce against one another. Were it otherwise, members of one generation could allocate the benefits of the world's resources to some communities and the burdens of caring for it to others and still potentially claim on balance to have satisfied principles of equity among generations.

Moreover, the fulfillment of intergenerational obligations requires attention to certain aspects of intragenerational equity. As is well-known, poverty is a primary cause of ecological degradation. Poverty-stricken communities, which by definition have unequal access to resources, are forced to overexploit the resources they do have so as to satisfy their own basic needs. As an ecosystem begins to deteriorate, the poor communities suffer most, because they cannot afford to take the measures necessary to control or adapt to the degradation, or to move to pristine areas.

Thus, to implement intergenerational equity, countries need to help poor communities to use the natural environment on a sustainable basis, to assist them in gaining equitable access to the economic benefits from our planet, such as potable water, and to help protect them from degraded environmental quality. As beneficiaries of the planetary legacy, all members of the present generation are entitled to equitable access to and use of the legacy. The future nationals of all countries will benefit from efforts of the present generation to protect the general planetary environment for future generations. Conversely, all will suffer if the present generation does not make such efforts.

I have proposed three basic principles of intergenerational equity. First, each generation should be required to conserve the diversity of the natural 
and cultural resource base, so that it does not unduly restrict the options available to future generations in solving their problems and satisfying their own values, and should also be entitled to diversity comparable to that enjoyed by previous generations. This principle is called "conservation of options." Second, each generation should be required to maintain the quality of the planet so that it is passed on in no worse condition than that in which it was received, and should also be entitled to planetary quality comparable to that enjoyed by previous generations. This is the principle of "conservation of quality." Third, each generation should provide its members with equitable rights of access to the legacy of past generations and should conserve this access for future generations. This is the principle of "conservation of access."

These proposed principles constrain the actions of the present generation in developing and using the planet, but within these constraints do not dictate how each generation should manage its resources.

These principles of intergenerational equity form the basis of a set of intergenerational obligations and rights, or planetary rights and obligations, that are held by each generation. These rights and obligations derive from each generation's position as part of the intertemporal entity of human society.

Planetary rights and obligations are integrally linked. The rights are always associated with obligations. They are rights of each generation to receive the planet in no worse condition than did the previous generation, to inherit comparable diversity in the natural and cultural resource bases, and to have equitable access to the use and benefits of the legacy. They represent in the first instance a moral protection of interests, which must be transformed into legal rights and obligations.

Planetary rights and obligations coexist in each generation. In the intergenerational dimension, the generations to which the obligations are owed are future generations, while the generations with which the rights are linked are past generations. Thus, the rights of future generations are linked to the obligations of the present generation. In the intragenerational context, planetary obligations and rights exist between members of the present generation. They derive from the intergenerational relationship that each generation shares with those who have come before and those yet to come. Thus, intergenerational obligations to conserve the planet flow from the present generation both to future generations as generations and to members of the present generation, who have the right to use and enjoy the planetary legacy.

Intergenerational rights of necessity inhere in all generations, whether these be immediately successive generations or ones more distant. There is no theoretical basis for limiting such rights to immediately successive generations. If we were to do so, we would often provide little or no protection to more distant future generations. Nuclear and hazardous waste disposal, the loss of biological diversity and ozone depletion, for example, have significant effects on the natural heritage of more distant generations. 
Intergenerational planetary rights may be regarded as group rights, as distinct from individual rights, in the sense that generations hold these rights as groups in relation to other generations-past, present and future. ${ }^{9}$ They exist regardless of the number and identity of individuals making up each generation. When held by members of the present generation, they acquire attributes of individual rights in the sense that there are identifiable interests of individuals that the rights protect. However, those interests derive from the fact that those living now are members of the present generation and have rights in relation to other generations to use and benefit from the planet. The remedies for violations of these rights will benefit other members of the generation, not only the individual. ${ }^{10}$

Developments in international law outside the field of the environment make acceptance of intergenerational rights a natural and desirable evolution. Indeed, international human rights law-the genocide convention, and the prohibition against racial discrimination, to cite two examples-are arguably directed as much to the protection of future, as to present, generations. The extinction of, for example, an entire people is more odious in law than the murder of an equal number of people constituting a minority of each of several groups. Similarly, discrimination denies an "equal place at the starting gate" not only to the generation of the suppressed group but (by implication) also to future generations. Provisions in other human rights agreements refer to rights of children and of the elderly, and to education and training, which are implicitly temporally oriented.

One might still ask whether it is not preferable to speak only of planetary obligations toward future generations without corresponding intergenerational rights. Can intergenerational obligations exist without rights? ${ }^{11}$ While rights are always connected to obligations, the reverse is not always true. Theoretically, an obligation need not always entail a right. For example, a moral obligation of charity does not give those who benefit a right to charity. The legal positivist Hans Kelsen hesitated to find a legal right connected to certain legal obligations.

\footnotetext{
${ }^{9}$ For a thoughtful analysis of group rights in relation to goods that are enjoyed together, see J. Waldron, Can Communal Goods Be Human Rights? (paper delivered at Conference on Development, Environment and Peace as New Human Rights, Oxford University, Oxford, England, May 28-31, 1987).

${ }^{10}$ The temporal dimension may offer a theoretical basis for unifying those human rights that we now consider to be group or social rights and for so-called new human rights. Group rights, such as cultural rights, have a temporal dimension since the community inherently extends over time. Theoretically, rights to development, to food, to health, and to the environment can be seen as intergenerational, or intertemporal, in that they are rights of access of each generation to use and benefit from our natural and cultural resources. See E. BROWN WEISs, supra note 1 , at $114-15$.

${ }^{11}$ Bryan Norton, a philosopher, argues that if one accepts the conceptual model of rights as limited to individual rights (which he does), it is preferable to recognize general obligations toward the integrity of environmental systems rather than to discuss environmental protection in the framework of rights, since this framework cannot encompass such categories as future generations, whose individual members are still contingent. Norton, Environmental Ethics and the Rights of Future Generations, 7 Soc. Theory \& Prac. 319, 337 (1981).
} 
If the obligated behavior of one individual does not refer to a specifically designated other individual . . . but refers only to the legal community as such, then . . . one is satisfied . . . to assume a legal obligation without a corresponding reflex right: for example in case of the legal norms that prescribe a certain human behavior toward some animals, plants, or inanimate objects by pain of punishment. It is forbidden to kill certain animals at certain times (or altogether), to pick certain flowers, to cut certain trees or to destroy certain historical monuments. These are obligations which-indirectly-exist toward the legal community interested in these objects. ${ }^{12}$

John Austin described some obligations as absolute duties, which exist independently of any correlative right. He defined absolute duties as those prescribing actions toward parties other than the one obliged, who are not determinate persons, such as members generally of an independent society and mankind at large. ${ }^{13}$

If we were to follow this analysis, we would contend that the obligations of the present generation to future generations constitute obligations or duties for which there are no correlative rights, because there are no determinate persons to whom the right attaches. Similarly, in the intragenerational context, obligations to conserve diversity, quality and access would be viewed as absolute duties for which there is no correlative right.

While this approach may be attractive, it ignores the fundamental temporal relationship that each generation has to all other generations and that gives rise to the rights of each generation to share equitably in the use of the planet and its natural resources. These rights focus discussion on the welfare of generations, what each generation is able to have and to enjoy, in a way that obligations cannot. If obligations of the present generation are not linked with rights, the present generation has a strong incentive to bias the definition of these obligations in favor of itself at the expense of future generations. Intergenerational rights have greater moral force than do obligations. They provide a basis for protecting the interests of all generations in a healthy and robust planet.

Professor D'Amato in his essay takes issue with the notion of rights of future generations to the planet by invoking Derek Parfit's famous paradox and combining it with the new theory of chaos. He argues that future generations cannot have rights because they are composed of individuals who do not exist yet and every intervention we take today to protect the environment affects the composition of these future individuals, robbing some potential members of future generations of their existence.

It is important to parse this analysis into its two component parts: that future generations cannot have rights because the individuals do not exist yet, and that actions to protect the environment for future generations will destroy the rights of some future individuals because different people will be born as a result of the intervention. The first is that future generations

${ }^{12}$ H. Kelsen, Pure Theory of Law 62 (M. Knight trans. 1969).

$131 \mathrm{~J}$. Austin, Austin's JurisprudenCe, LeCtures on JurisprudenCe 413-15 (1873). 
cannot have rights, because rights exist only when there are identifiable interests, which can only happen if we can identify the individuals who have interests to protect. Since we cannot know who the individuals in the future will be, it is not possible for future generations to have rights.

This paradox assumes the traditional conceptual framework of rights as rights of identifiable individuals. The planetary, or intergenerational, rights proposed in In Fairness to Future Generations are not rights possessed by individuals. They are, instead, generational rights, which must be conceived of in the temporal context of generations. Generations hold these rights as groups in relation to other generations-past, present and future. This is consistent with other approaches to rights, including the Islamic approach, which treats human rights not only as individual rights, but as "rights of the community of believers as a whole." ${ }^{14}$ They can be evaluated by objective criteria and indices applied to the planet from one generation to the next. To evaluate whether the interests represented in planetary rights are being adequately protected does not depend upon knowing the number or kinds of individuals that may ultimately exist in any given future generation.

Enforcement of these intergenerational rights is appropriately done by a guardian or representative of future generations as a group, not of future individuals, who are of necessity indeterminate. While the holder of the right may lack the capacity to bring grievances forward and hence depends upon the representative's decision to do so, this inability does not affect the existence of the right or the obligation associated with it.

Now it may be argued that such rights do depend upon knowing at least the number of individuals in the future, because if the earth's population continues to grow rapidly, the amount of diversity and degree of quality that must be passed on will be higher than if the population in the future were at the same level or less than it is today.

But, if anything, the existence of these generational rights to the planet may constrain the population policies of present and future generations. Whether a generation chooses to meet its obligations by curtailing exploitation, consumption and waste or by constraining population growth is a decision it must make. The fact that future generations have a generational right to receive the planet in a certain condition puts constraints on the extent to which a present generation can ignore this choice.

The second part to Professor D'Amato's argument is that if we intervene to conserve the environment to protect future generations, we cannot succeed in protecting them because our intervention will cause a different group of individuals to emerge. But since the rights of future generations exist only as generational rights, it does not matter who the individuals are or how many they may be. Only at the point where the individuals are born and by definition become members of the present generation do the generational rights attach to individuals.

Professor D'Amato's response is that "[f]uture generations are not an abstraction; they consist of individuals." But they do not consist of individ-

\footnotetext{
${ }^{14}$ M. Khadduri, The Islamic Conception of Justice 233 (1984).
} 
uals until they are born, and hence it is necessary and appropriate to speak of future generations qua generations as having rights in relation to the planet.

Professor D'Amato correctly points out that the composition of future generations cannot be known in advance, in part because it is affected by actions of the present generation. Indeed, he does not make his own case as strongly as he might. For example, we do not need to limit ourselves to ascribing these effects to subtle changes in the biochemistry of conception, as Professor D'Amato does in his amusing excursion into the dynamics of egg and sperm.

Virtually every policy decision of government and business affects the composition of future generations, whether or not they are taken to ensure their rights under the guidelines enunciated above. Decisions regarding war and peace, economic policy, the relative prosperity of different regions and social groups, transportation, health, education-all influence the demographics and the composition of future generations by affecting the lives and fortunes of the present generation: who will succeed and prosper, who will marry whom, who will have children, and even who will emigrate.

In Fairness to Future Generations takes the view that our planetary obligations to future generations are owed to all the earth's future human inhabitants, whoever they may be. This opens the possibility that these decisions, too, deserve to be scrutinized from the point of view of their impact on future generations. Professor D'A mato's approach reflects an unnecessarily constrained view of human rights law that would shut off a useful and broadly acceptable theoretical underpinning to sustainable resource development. The possibility that intergenerational equity may place limits on our actions is an important new area of human rights research.

Such limitations should be applied very narrowly, lest the rights of future generations develop into an all-purpose club to beat down any and all proposals for change. But surely long-term environmental damage is a good place to begin. Future generations really do have the right to be assured that we will not pollute ground water, load lake bottoms with toxic wastes, extinguish habitats and species or change the world's climate dramatically -all long-term effects that are difficult or impossible to reverse-unless there are extremely compelling reasons to do so, reasons that go beyond mere profitability.

Professor D'Amato invokes chaos theory to justify his contention that any environmental intervention will produce different individuals in the future than would otherwise have been produced. But he overlooks the most important implication of chaos theory for the environment and for future generations: namely, that systems do not proceed on orderly, linear paths of change, but rather that they will abruptly change..$^{15}$ This can be demonstrated on a home computer, using a very simple program. It has been

\footnotetext{
${ }^{15}$ For catastrophe theory, see R. Thom, Mathematical Models of Morphogenesis (1983); for the theory of complex systems, see I. Prigogine \& I. STENGERs, Order OUT OF Chaos: Man's New Dialogue with Nature (1984). For a concise review of the influence of chaos theory, see Chaos Theory: How Big an Advance?, 245 SCIENCE 26 (1989).
} 
suggested that there may be key breaking points in our global environmental system, beyond which systems will reorganize and substantially change their properties. ${ }^{16}$ If we are concerned about future generations, it is important to try to predict these breaking points. More importantly, the best tool that we could give future generations to respond to abrupt changes and reorganizations is a robust planet, which requires conserving a diversity of resources so that future generations have greater flexibility in designing responses.

Professor D'Amato proposes that there is a "preverbal sense of morality" that tells us not to waste resources, degrade the environment or wantonly kill animals. But, if anything, history in the last few centuries suggests that our natural instincts are self-indulgent. We have desecrated environments, wasted resources and slaughtered animals purely for pleasure or for modest personal gain. It may be that the human species carries both a selfish gene and an altruistic one, as the sociobiologists tell us, ${ }^{17}$ but it is hardly sufficient to rely on the generous gene to build a theory of morality to overcome the selfish genes, without more.

In Fairness to Future Generations relies on a fundamental norm of equality among generations of the human species in relation to the care and use of the natural system. But it recognizes that we are part of the natural system and that we, as all other generations, must respect this system. We have a right to use and enjoy the system but no right to destroy its robustness and integrity for those who come after us.

Whether we rely on a beneficent "preverbal sense of morality" toward the planet and its resources or on theories rooted in the welfare of the human condition and the ecological system of which people are a part, there is a shared recognition that the present generation has an obligation to care for the planet and to ensure that all peoples can enjoy its services.

EDITH BROWN WeISS*

\section{Our Responsibility to Future Generations}

In recent years, lawyers have begun to join ecologists in debating whether there are-or should be-obligations to protect the interests of future generations. ${ }^{1}$ This legal debate was preceded by a philosophical one, dating back to the early 1970 s, on the emergence of a new or "ecological" ethic

\footnotetext{
${ }^{16}$ G. Gallopin, President, Fundación Bariloche, discussion with author, June 1986. This is consistent with the scientific paradigms in the theories of catastrophe and of the dynamics of complex systems far from equilibrium.

${ }^{17}$ See, e.g., J. \& J. BALdwin, Beyond Sociobiology (1981). Sociobiologists assert that there are four types of inherent behavior that explain all our social behavior: selfish, altruistic, cooperative and spiteful. Humans act so as to try to ensure that their genes will be carried forward into succeeding generations. $I d$. at 49-50.

* Of the Board of Editors.

${ }^{1}$ For the German-speaking context, see P. SALAdin \& C. A. Zenger, ReChTE KÜNFtiger GENERATIONEN (1988).
} 